\title{
The Great Recession and Social Preferences: Evidence from Ukraine*
}

\author{
Ralph De Haas ${ }^{\dagger}$ \\ Milena Djourelova \\ Elena Nikolova ${ }^{\S}$
}

December 16, 2015

\begin{abstract}
We use detailed survey data to document stark differences between West and East Ukraine when it comes to household attitudes toward market-based economies and democratic institutions. Along both of these dimensions, Eastern Ukrainians are decidedly less supportive of liberal systems. We also find that economic attitudes changed in response to the global financial crisis. West Ukrainian households who were affected more extensively by the crisis were more disappointed with the market and private ownership, while in Eastern Ukraine economic attitudes became less pro-market across the board. Our evidence suggests that attitudes and values are determined by both deep-rooted factors and more transient macroeconomic shocks.
\end{abstract}

${ }^{*}$ We would like to thank Sergei Guriev for many helpful discussions and advice, Yuriy Gorodnichenko and participants at the JCE Symposium on Ukraine for useful comments, and Hayk Gyuzalyan for assistance with data on Ukrainian media. The views expressed in this paper are those of the authors only and not necessarily of the EBRD.

${ }^{\dagger}$ EBRD and Tilburg University. Email: dehaasr@ebrd.com

${ }^{\ddagger}$ Universitat Pompeu Fabra. Email: mdjourel@gmail.com

$\S$ EBRD. Email: nikolove@ebrd.com 


\section{Introduction}

Under what circumstances do individual preferences persist, and when are they malleable? Are personal beliefs influenced by deep-rooted historical factors or rather by more transient macroeconomic shocks? The Great Recession, which brought unemployment and economic fragility throughout the world, has turned the spotlight on these questions. This debate has been especially important for the transition countries in emerging Europe. This is the case not only because this region was much more affected by the financial crisis than Western Europe, but also because political, social and cultural cleavages are particularly salient within as well as across transition countries.

In this paper, we contribute to this discussion by exploring the drivers of social preferences in Ukraine. We exploit disaggregated data from the second round of the EBRD-World Bank Life in Transition Survey (LiTS II), a nationally representative household-level survey administered in fall 2010. In addition to household and demographic information, the survey includes questions on a wide range of attitudes and values. Importantly, it also collects detailed information about households' exposure to the global financial crisis.

Our analysis, which focuses on attitudes towards market economy and democracy, documents stark differences between West and East Ukraine. On average, those living in the Eastern part of the country are more than $35 \%$ less likely to be in favor of a market-based economic system and $42 \%$ less likely to support democratic institutions. As we argue below, this evidence provides partial support for theories focusing on persistent cultural differences as a driver of attitudes. However, we also find that economic attitudes were affected greatly by the crisis, and that this effect differed markedly between West and East Ukraine. Households who were hit hardest by the Great Recession were most disappointed with the market economy and this was particularly so in the West. In contrast, in Eastern Ukraine the declining support for market economy was unrelated to crisis exposure. The disillusionment 
with markets among Western Ukrainians was stronger for households who, as a result of the financial crisis, had to cut down on food consumption, education or had to delay payments on utilities and loans. While we find that crisis-affected Western Ukrainians were also less likely to approve of democracy, this effect is less robust.

Although we lack a longitudinal data set, the richness of the survey which we use allows us to look into the role of some suggestive mechanisms. Since our data are from 2010, one possibility could be that the East-West cultural divide which we uncover is in fact a consequence of different early transition paths. Accounting for sub-national indices capturing the severity of the early transition shock (using data on night-time light intensity as a proxy for local economic activity) suggests that respondents in regions which experienced a greater initial income loss were also more affected by the recent crisis. Even so, our earlier results remain broadly similar. A second question is whether our specifications are simply capturing differences between Russian and non-Russian speakers (and their potentially different cultural mindsets). The latter may dominate in the West and the former in the East. Our findings speak to the contrary, since additional controls for linguistic, cultural and historical ties with Russia are insignificant.

Our empirical setup raises two potential identification concerns. First, since the analysis is based on cross-sectional data, unobserved individual heterogeneity could be a problem, particularly since the sample of respondents living in East and West is not random. Second, the extent to which each household was affected by the Great Recession is unlikely to be exogenous. We adopt several approaches to address these issues. First, we control for a wide range of observable characteristics that are likely to be correlated with crisis exposure, place of residence and preferences. These include household income, employment status and education, as well as Primary Sampling Unit (PSU) characteristics such as urbanity, latitude and longitude. Second, to rule out geographic sorting of respondents, in all specifications we control for whether the respondent has ever moved. We show that all our results are robust 
to accounting for out-migration from Ukrainian regions.

Third, we instrument household crisis exposure with the pre-crisis composition of bank branches in a respondent's primary sampling unit using detailed data from the second Banking Environment and Performance Survey (BEPS II, administered by the EBRD). Previous work has shown that the crisis was an exogenous shock which was transmitted to emerging Europe mainly through the branch networks of foreign-owned banks (Popov and Udell 2012). We therefore exploit local variation in the balance-sheet strength of foreign banks in each PSU to create a branch-weighted proxy for the intensity with which the global financial crisis transmitted to specific geographical localities within Ukraine. We show that households in PSUs dominated by branches of foreign parent banks which were heavily dependent on (unstable) wholesale funding were most affected by the crisis.

Our work relates to several strands of the literature. First, we contribute to a large scholarship which has shown that cultural differences can affect a variety of economic and political outcomes (see, for instance, Algan and Cahuc (2010); Gorodnichenko and Roland (2011); Guiso et al. (2006); tab (????)). In addition, we complement an important literature on the origin of preferences. On the one hand, scholars have argued that culture is stable, as it may be transmitted vertically (Bisin and Verdier 2001) or influenced by long-run historical events (Alesina et al. 2013; Becker et al. 2014; Grosfeld et al. 2013; Nunn and Wantchekon 2011). On the other hand, there is evidence that norms can change relatively rapidly. Beliefs can be affected significantly by macroeconomic and wealth shocks (Ananyev and Guriev 2013; Di Tella et al. 2007; Fisman et al. 2013; Giuliano and Spilimbergo 2014; Grosjean et al. 2013), access to information (Kuziemko et al. 2013) and political experiences (Alesina and FuchsSchündeln 2007). We review these contributions in more detail, particularly as they relate to the Ukrainian context, in the next section of the paper.

This paper enriches the literature in four important ways. Our results suggest that deep-rooted factors and more short-lived macroeconomic shocks may interact to determine 
preferences for the market and democracy. This implies that claims emphasizing the importance of either mechanism may be only partially correct. Unlike much of the previous literature, we do not find that the East-West divide or the crisis explain trust, preferences for redistribution and risk, views about state paternalism, civic activity and social capital, and beliefs about the importance of effort versus luck for advancing in life. From an econometric point of view, focusing on a single large country helps to avoid identification biases present

in cross-country regressions, on which much of the existing literature is based. Our contribution also stems from the fact that we are able to use disaggregated data from Ukraine prior to the Russia-Ukraine conflict which have not been explored before.

This paper is organized as follows. The next four sections present our conceptual framework, data, empirical approach and results, respectively. The final section concludes.

\section{Macroeconomic shocks and the persistence of pref- erences}

Social scientists studying the origins of preferences and beliefs face an important challenge: pinpointing the circumstances under which preferences persist and when they change. On the one hand, several influential studies argue that cultural values are determined by long-run historical events. For instance, Putnam et al. (1994) attributes the lack of civic competence in Southern Italy to its autocratic Norman regime in medieval times (as compared to Northern Italy, which consisted of city-state governments). Voigtländer and Voth (2012) demonstrate that in Germany, anti-Semitic attitudes and behavior persisted for more than 600 years. In Africa, Nunn and Wantchekon (2011) argue that the slave trade led to permanently lower levels of trust in slave-sending countries today.

More recently, arguments focusing on the persistence of preferences have been applied to the Eastern European context as well. Grosfeld et al. (2013) show that current residents of 
the Pale (the area to which Jews were confined in the Russian empire) have lower support for the market, vote more for anti-market parties, but are at the same time also more trusting. A possible mechanism suggested by the authors is that ethnic hatred toward Jews generated both a persistent anti-market culture and trust among the non-Jewish population of the Pale. In a similar vein, Becker et al. (2014) use geographical regression discontinuity to show that Eastern Europeans living in areas which were historically affiliated with the Habsburg empire have higher trust and less corruption in courts and public services today. Both of these papers use the first round of the LiTS (conducted in 2006).

On the other hand, a different strand of the literature shows that culture is strongly affected by income shocks, although neither the direction nor the longevity of such effects is clear-cut. Due to data availability, much of this work has focused on advanced countries such as the U.S. Looking at welfare attitudes, Margalit (2013) finds that voter preferences regarding welfare policy depend strongly on personal economic circumstances, but also that these attitudes do not persist: as job losers regain employment, their support for redistribution decreases significantly. In contrast, Giuliano and Spilimbergo (2014) show that the effect of recessions on beliefs is long-lasting. Individuals who experienced a recession when young are more likely to believe that success in life depends more on luck than effort, support government redistribution, and vote for left-wing parties. Using lab experiments, Fisman et al. (2013) instead demonstrate that subjects affected by the recession exhibit higher levels of selfishness and greater emphasis on efficiency versus equality. Lastly, Mian et al. (2014) show that financial crises tend to result in shifting political preferences and greater ideological divides within countries. The authors suggest that debtors - such as households with mortgages or other loans - adjust their preferences in particular as they see their net worth decline most during a financial crisis.

To the best of our knowledge, only two papers have looked at the impact of macroeconomic shocks on preferences in Eastern Europe. Grosjean et al. (2013) (who also exploit 
LiTS 2010) show that preferences for the market and democracy are highly sensitive to large swings in the business cycle, and that people tend to reduce their support for the prevalent economic and political system when hit by a negative income shock. Similarly, Ananyev and Guriev (2013) find that Russian regions which were more strongly affected by the recent financial crisis experienced a drop in interpersonal trust. ${ }^{1}$

Credibly identifying the drivers of individual preferences, be they long-term or more transient, is a challenging task. Exogenous variation in economic conditions is rare, and macroeconomic and historical changes covary with other observed and unobserved processes. Although experimental approaches (in the spirit of Fisman et al. (2013)) can help with causal inference, they are often focused on a very narrow population in a developed country. At the very least, testing for effects in a different context will help validate existing insights and further the debate to issues not raised by research in advanced settings. At the other end of the spectrum, using cross-country analyses may also be problematic due to data heterogeneity and endogeneity concerns (Pande and Udry 2005).

In this paper, we use three complementary approaches to aid identification. First, by focusing on within-country variation in economic conditions, geography and preferences, we avoid the biases typical of cross-country work. Second, not only do we use a very fine-grained individual measure of crisis exposure, but we also account for a wide range of observable individual characteristics, such as education and migration history. Third, to rule out possible endogeneity of our crisis impact measure or reverse causality from preferences, we implement a new instrument for individual exposure to the Great Recession. In particular, we exploit cross-locality variation in the extent to which local banking markets were vulnerable to deteriorating funding conditions of foreign parent banks during the crisis. We describe in more detail our data and empirical specification in the next two sections.

\footnotetext{
${ }^{1}$ Whether positive income shocks may generate direction-symmetric effects (in Eastern Europe or elsewhere) is unclear. In Argentina, squatters who (quasi-randomly) received a housing title also developed stronger pro-market preferences (Di Tella et al. 2007).
} 


\section{Data}

Our main data source is the second round of the EBRD/World Bank Life in Transition Survey (LiTS) which was conducted in 29 transition countries and Turkey, Italy, France, Germany, Sweden and the UK in the summer of 2010 using face-to-face interviews. LiTS is a nationally representative survey that combines modules related to economic and demographic characteristics, attitudes and values, labor, education and entrepreneurship, climate change, and the impact of the global financial crisis. Survey respondents (aged 18 and above) were drawn randomly, using a two-stage sampling method. Census enumeration areas, stratified by region and by level of urbanity and selected with probability proportional to size, served as primary sampling units (PSUs), while households served as secondary sampling units. In Ukraine, 75 PSUs consisting of 20 households each were selected. We supplement these data with external data on PSU latitude and longitude and detailed information on the geographical distribution of bank branches across Ukraine as taken from the second EBRD Banking Environment and Performance Survey (BEPS II).

\subsection{Dependent variables}

We construct our dependent variable measuring support for market economy based on answers to the following question: With which one of the following statements do you agree most? (1) A market economy is preferable to any other form of economic system; (2) Under some circumstances, a planned economy may be preferable to a market economy; and (3) For people like me, it does not matter if the economic system is organised as a planned economy or as a market economy. To capture preferences for democracy, we use answers to the following question: With which one of the following statements do you agree most? (1) Democracy is preferable to any other form of political system; (2) Under some circumstances, an authoritarian government may be preferable to an autocratic one; and (3) For people like 
me, it does not matter if a government is democratic or authoritarian. In both cases, we create a dummy variable which codes answer option (1) as "1", and answer options (2) and (3) as "0". We drop respondents who answered "Don't know."

\subsection{Independent variables}

Exposure to the crisis During the period 2004-2007, Ukraine experienced a credit boom fueled by rapid inflows of foreign capital that was intermediated locally through predominantly foreign-owned banks. Foreign-currency denominated consumer lending and household consumption expanded rapidly. With the onset of the global financial crisis in 2008, this process came to an abrupt end. Deleveraging by branches of foreign parent banks that were liquidity-starved and capital-constrained, combined with a substantial devaluation of the hryvnia, meant that many households experienced limited access to new credit or faced repayment problems as their debt burden had suddenly increased in real terms. As a result, households had to make quick and often substantial adjustments to their consumption of goods and services.

We use two complementary measures of household exposure to the crisis: a subjective and an objective one. The first measure is based on a question which asks to what extent the crisis affected the respondent's household in the past two years, with answer options: (1) not at all; (2) just a little; (3) a fair amount; and (4) a great deal (we label this index as subjective crisis impact in the regressions below). This index is coded on a 0-3 scale. Our variable capturing objective crisis exposure exploits information from the following question: In the past two years, have you or anyone else in your household had to take any of the following measures as the result of a decline in income or other economic difficulty? The question then gives a choice of 17 answer options (to which respondents can answer yes or no), including a decrease in food consumption, tobacco and leisure goods; delaying or withdrawing from university or a training course; reducing health expenses and doctor visits; delaying utility 
payments or having utilities cut; default on a loan; sale of an asset; or migration. For each answer option, we create a dummy variable equal to 1 if the respondent took the particular action, and 0 otherwise. We obtain the objective crisis impact index by adding up these 17 dummy variables. ${ }^{2}$

Additional variables Our dummy for East Ukraine is based on geographical coordinates of the Primary Sampling Unit (PSU) in which the respondent currently lives. PSUs in East Ukraine are located in the following regions: Autonomous Republic of Crimea, Dnipropetrovsk, Donetsk, Kharkiv, Kherson, Luhansk, Nikolayiv, Odessa and Zaporizhzhya. ${ }^{3}$ Figure ?? illustrates that the East-West divide is culturally and politically salient: the majority of East Ukrainians are Russian speakers who supported Viktor Yanukovych in the 2010 presidential elections. Our regressions also include controls for PSU latitude and longitude (from Nikolova and Simroth (2015)) and level of urbanity. At the individual level, we control for age, age squared, whether the respondent has ever successfully started a business, whether the respondent has been unemployed in the past 12 months (excluding those who are unemployed but have started a business), respondent's self-identified household income (on a ten-step ladder), education, gender, health status, whether the respondent has lived in the same locality all their life, and whether the respondent or any family members were part of the former communist party. Table ?? in the online Appendix provides more information on our dependent and independent variables.

\footnotetext{
${ }^{2}$ This index is equivalent to the synthetic consumption response index of Grosjean et al. (2013). Unfortunately, due to a large number of missing observations for Ukraine, we are unable to utilize an equally useful survey question which asks whether the household head or another household member lost their job between 2008-2010.

${ }^{3}$ West Ukraine includes the regions of Cherkasy, Chernivtsi, Ivano-Frankivsk, Khmelnytskiy, Kirovohrad, Kyiv, Lviv, Poltava, Rivne, Sumy, Ternopil, Vinnytsya, Volyn, Zakarpattya and Zhytomyr.
} 


\subsection{Graphical evidence and summary statistics}

Figure 1 summarizes the differences in preferences for market economy and democracy in East and West Ukraine in 2006 and 2010. The figure shows that in 2006, just before the global financial crisis, support for a market-based economic system was roughly similar in both parts of the country, while support for a democratic political system was significantly lower in the East. The 2010 data indicate that residents of the East became significantly less in favor of both a market economy and democratic institutions. At the same time, on average, economic attitudes hardly shifted in the Western part of the country, while support for democracy dropped in line with what happened in the East. The resulting differences are striking: in 2010, less than 30\% of Eastern Ukrainians support market-based economic systems, while the corresponding figure for Western Ukraine remains at around $42 \%$.

The gap is slightly bigger when it comes to approval of democracy, with $34 \%$ of Eastern Ukrainians in favor of democratic institutions, as opposed to nearly half of Western Ukrainians. Figures 2 and 3 put these large differences into an international perspective by adding data (for 2010 only) for other countries in the transition region as well as five Western European comparators (UK, France, Germany, Sweden and Italy). Figure 2 shows that while support for a market-based economic system is relatively high in West Ukraine (even higher than in France, Italy and the UK), Eastern Ukrainians are very disapproving of the market. The within-country difference in support for a democratic political system is also substantial (Figure 3). In fact, Eastern Ukrainian households display the lowest support for democracy compared to all countries that were part of the LiTS 2010 survey.

Table ?? presents summary statistics for the variables which we use in our regression analysis. Our observations are split roughly equally between the two parts of the country, and respondents in East and West Ukraine are similar across a variety of dimensions. Respondents in the East are significantly more likely to be Russian speakers and marginally more likely to have been members of the former communist party and to have a post- 
secondary/university degree. Interestingly, the (self-reported) impact of the crisis seems to be similar across the East and the West.

\section{Empirical specification}

To investigate differences in preferences for the market and democracy between Eastern and Western Ukrainians, we run OLS regressions of the following type:

$$
\text { Attitude }_{i p}=\alpha_{i p}+\beta_{1} \text { EastDummy }_{p}+\beta_{2} \text { Crisis }_{i p}+\beta_{3} \text { EastDummy }_{p} \text { Crisis }_{i p}+\beta_{4} \boldsymbol{X}_{i p}+\beta_{5} \boldsymbol{Y}_{\boldsymbol{p}}+\epsilon_{i p}
$$

where for each respondent $i$ in primary sampling unit $p$, Attitude $i_{i p}$ is a dummy variable capturing either support for market economy or democracy; EastDummy $y_{p}$ is a dummy for whether the PSU is located in East Ukraine, Crisis $s_{i p}$ is one of the two crises indices, $\boldsymbol{X}_{\boldsymbol{i}}$ is a matrix of individual-level controls as described above and $\boldsymbol{Y}_{\boldsymbol{p}}$ is a matrix of PSU-level controls (including latitude, longitude and a dummy for urban vs. rural locality). We include survey weights to ensure that the data are representative at the country level and use robust standard errors. All the results are very similar if we either cluster the errors at the level of administrative regions, ${ }^{4}$ PSU level, or instead calculate standard errors using the wildbootstrapped approach of Cameron et al. (2008) (to explicitly take into account the small number of clusters in the specifications when we consider separately East vs. West Ukraine). Note that although around 1,599 individuals were interviewed in Ukraine, missing data on some variables implies that the sample with which we work contains between 900 and 1,114 observations.

\footnotetext{
${ }^{4}$ Ukraine has 25 administrative regions.
} 


\section{Results}

\subsection{Main results}

Table 1 presents our results using support for market economy as the dependent variable. In Column (1), we include the East dummy, the Objective crisis impact index and their interaction (in addition to the individual and PSU controls described above). In column (2), we include our Subjective crisis impact index, again along with its interaction with the East dummy. In both columns the results are similar. Focusing on the point estimates in column (1), the coefficient on Objective crisis impact implies that a one-standard deviation increase in this variable weakened a household's support for the market in Western Ukraine by $9.4 \%$. This is a sizeable effect, as on average only around $36 \%$ of Ukrainians are in favor of the market. ${ }^{5}$ In contrast, the impact of the crisis on market attitudes in Eastern Ukraine (obtained by adding the coefficient on Objective crisis impact and East* Objective crisis impact) is nearly 0 .

In columns (3) and (4), we rerun the specification in column (1) separately on East and West Ukraine, and obtain very similar results. Figure 4 shows the same results graphically. ${ }^{6}$ Among households unaffected by the financial crisis (located on the very left of the graph), clear differences in market preferences prevail among those based in the West versus those in the East. Yet, among households who were more negatively impacted by the crisis we observe a gradual blurring of the differences in preferences between both parts of the country. In fact, the preferences of those Western Ukrainian households impacted hardest by the crisis are no longer statistically different from those of their Eastern counterparts. Of course, this is also due to the fact that our estimates become less precise as the number of households severely hit by the crisis diminishes in our sample.

\footnotetext{
${ }^{5}$ See Table ?? for means and standard deviations of all variables.

${ }^{6}$ Figures ?? and ?? replicate Figure 4 using a non-parametric approach.
} 
The signs of the additional controls are in the expected direction. Respondents who are unemployed are significantly less likely to support the market, as are those who are male and who have family members who were part of the former communist party. In contrast, higher education (particularly having post-secondary and university degree), health and income are associated with stronger pro-market preferences.

In Table 2, we re-run the regressions in column (1) of Table 1 but instead use more disaggregated crisis impact indices capturing whether the household had to reduce food consumption; the consumption of luxury goods or leisure activities; education; health services; or delay payments of utilities or loans. All of these sub-indices are recoded on a 0-1 scale for comparability. The table shows that Western Ukrainians who had to reduce their spending on education or food or had to delay payments on utilities or loans are particularly disapproving of the market.

Next, Table 3 investigates the determinants of preferences for democratic institutions. On average, respondents in the East are between 35\%-40\% less likely to support democracy, as compared with those in the West. Column (1) demonstrates that Eastern Ukrainians hit by the crisis are slightly more likely to support democracy than Western Ukrainians, but the effect is smaller compared to the one in Table 1 and only marginally significantl. ${ }^{7}$ Like in Table 1, the crisis also eroded support for democracy in West Ukraine, though the latter impact is imprecisely estimated. We find a similar negative (and statistically significant) effect of the crisis on political preferences in West Ukraine in columns (3) and (4), which replicate the regressions in column (1) separately for West and East Ukraine, respectively. However, this result is not robust to using the subjective crisis impact variable in column (2). Overall, the evidence suggests that the crisis negatively affected preferences for democracy in West Ukraine, but that it cannot explain the equivalent drop in support

\footnotetext{
${ }^{7} \mathrm{~A}$ one-standard deviation increase in the objective crisis impact index leads to a $6.3 \%$ decrease in democracy support, or around $15 \%$ relative to the mean of the dependent variable.
} 
for democracy in East Ukraine. At the same time, results are less clear-cut compared to those when support for the market is considered, so they should be interpreted with caution. In unreported specifications, we re-ran the regressions in Table 3 for democratic preferences using interactions between the east dummy and disaggregated crisis sub-indices, without finding any significant effects.

The control variables in Table 3 exhibit some interesting patterns. Respondents who are older, ${ }^{8}$ who set up a business at some point in their lives, and who have secondary education or higher are more likely to support democracy. To conserve space, we omit these additional controls from the tables to follow.

\subsection{Robustness}

\subsubsection{IV estimations}

A potential concern is that our measure of household-level crisis impact may be correlated with unobservable household or locality characteristics, such as ability or culture. In addition, it is possible that anti-market individuals may be more likely to report that their families were hit harder by the crisis (which may partially explain the stronger coefficients obtained in Table 2). To address such issues related to omitted variables, endogeneity and reverse causality, we adopt an IV approach where we instrument crisis exposure with the precrisis composition of bank branches in the household's primary sampling unit. We combine information on bank branch networks from the second EBRD Banking Environment and Performance Survey (BEPS II) with geographic coordinates of the PSUs and the individual branches. We match the households in each PSU with the branches located within a circle with a 10 kilometer radius around the center of the PSU. All our results hold when we match based on a 5 kilometer radius or match using the names of the PSU and of the localities

\footnotetext{
${ }^{8}$ The quadratic age effect suggests an inverted U-shape effect of age on preferences for democracy, with the peak occurring at 57 years.
} 
where the branches are based. Our preferred specification uses the 10 kilometer cutoff as it maximizes the number of observations in the regressions.

In line with Popov and Udell (2012), we treat the global financial crisis as an exogenous shock that was first and foremost transmitted to Ukraine through the branch networks operated by foreign-owned banks. We therefore exploit local variation in the financial soundness of the foreign banks active in each PSU to create branch-weighted proxies of the intensity with which the global crisis affected specific localities within Ukraine. ${ }^{9}$ By focusing on the financial health of the foreign (rather than domestic) parent banks of the branches operating across Ukraine, our instrument is unlikely to be affected by PSU economic conditions. ${ }^{10}$

We construct our instrument by using the branch-weighted ratio of gross loans to customer funding in 2006. This ratio was on average 178 in 2006, indicating that many banks in Ukraine operated on a small depositor base and had become highly dependent on wholesale funding by the time the crisis unraveled. We hypothesize that branches of banks that were more dependent on wholesale funding at the outbreak of the crisis, had to reduce lending the most. ${ }^{11}$ This implies that households located in PSUs populated by such branches were more likely to end up credit constrained and, as a result, to be negatively affected by the crisis. Moreover, we expect that in PSUs which have many branches of wholesale-dependent foreign banks more foreign-currency denominated consumer and mortgage lending took place before the onset of the crisis. The unexpected devaluation of the Ukrainian hryvnia in October 2008 will therefore have affected households in these PSUs more severely as they must have experienced a sharp and sudden increase in the real value of their outstanding debt.

Table 4 presents our IV results. To keep the specifications simple, we only show results where we split the sample into West and East. For comparability, columns (1) and (4) repli-

\footnotetext{
${ }^{9}$ We exclude 20 PSUs without any foreign bank branches.

${ }^{10}$ Given the large size of the multinational banks that operate in Ukraine, our instrument is also arguably exogenous to the economic situation in Ukraine as a whole.

${ }^{11}$ See De Haas and Van Lelyveld (2014) for a discussion.
} 
cate the OLS results from Table 1 (for West and East Ukraine, respectively) on the sample of PSUs which have at least one foreign-bank branch. Columns (2) and (5) presents results with the wholesale funding instrument. In line with our priors, the first-stage estimates indicate that households surrounded by foreign banks that operated with a high loan-to-deposit ratio, were impacted more by the crisis and had to adjust their consumption patterns the most.

The second-stage results confirm that while the crisis had a strong and negative impact on preferences for a market-based economic system in the West, such an impact was absent in the Eastern part of Ukraine. In fact, the IV estimates in column (2) are several times stronger (in absolute value) compared to those in column (1), suggesting that omitted variables bias the OLS results downward. For instance, ability is likely to be positively correlated with market preferences and negatively correlated with crisis exposure. Failing to account for this variable in the OLS specifications (which use the less precise self-reported crisis impact index) will lead to attenuation bias.

\subsubsection{Validity of the IV approach}

The adopted IV strategy would be valid provided that three conditions are satisfied: (1) the first-stage relationship must be strong; (2) the instrument should not affect preferences for the market directly; and (3) the instrument should not be correlated with the error term in the second-stage regression. We examine the validity of each of these assumptions below.

First, our regressions indicate that the instrument indeed explains a significant portion of the variation in household crisis exposure, with F-statistics comfortably above 10. Second, an important identifying assumption underlying our instrumentation strategy is that the financial health of these mainly Western European parent banks only affected market preferences of Ukrainian households through the impact on local lending conditions. This seems a reasonable assumption as the lending activities of the local branch networks are the only 
direct link between Western parent banks and local households. There is no cross-border lending from parent banks to local households and small firms.

Third, concerns about omitted unobservable characteristics are less salient as our estimates include a wide range of individual and PSU controls. One may nevertheless worry that foreign banks with weaker balance sheets - those with a high pre-crisis level of wholesale funding - sorted into economically weaker PSUs that were more exposed to the crisis. Similarly, foreign banks may have positioned themselves in areas with higher export intensity, and the economic shock which our instrument is designed to capture may be determined by exposure to foreign markets. To partially address this, in columns (3) and (6) of Table 4 we exclude all branches opened in 2005 and later. This changes our results very little. If anything, our first-stage relationships are even stronger. This shows that our results are robust to the exclusion of these recent - and potentially endogenously sorted - branches.

What is more, endogenous sorting by banks is unlikely for an additional reason: foreign bank entry almost exclusively occurred through the take-over of large pre-existing branch networks of state banks. Strategic investors only entered Ukraine's banking system relatively late, in a privatization wave that occurred during 2005-06 (Ahunov et al. 2013). This sudden and rapid foreign bank entry followed the removal of Ukraine from the money-laundering black list of the Financial Action Task Force in February 2004 (Dushkevych and Zelenyuk 2007). Because the take-over wave happened just before the onset of the global financial crisis, the new foreign bank owners had little time to modify their recently acquired branch networks by closing or opening branches.

\subsubsection{Additional robustness checks}

We further probe the robustness of our results in Table 5. To rule out that findings are driven by geographic sorting of respondents, in column (1) we control for the total regional emigration rate, while in column (2) we control for the regional share of emigrants who went 
to Russia, the EU-27 countries, and the rest of the world (all measures are from Commander et al. (2013) who collected them via a survey conducted in the second half of 2011). In both cases our results are very similar to those in Table 1, while the coefficients on the additional variables are insignificant, indicating that our findings are not driven by crisisrelated regional population shifts. In column (3), we include a proxy for individual wealth (calculated as the sum of all assets owned by the respondent's household) which again makes

little difference to the results. In column (4), we use a different dependent variable to proxy for pro-market preferences: the extent to which the respondent favors private ownership, on a 1-10 scale. The results parallel those in Table 1 which is reassuring. In unreported specifications, we also excluded Kiev from the regressions, and clustered the standard errors at the regional and PSU levels, which left the results unchanged.

\subsubsection{Looking beyond preferences for market and democracy}

Are East and West Ukrainians different when it comes to other cultural attitudes? In unreported results, we re-ran our baseline specification using a variety of additional dependent variables (based on questions from LiTS II), such as trust in others, preferences for redistribution and risk, views about state paternalism, civic activity and social capital, and beliefs about the importance of effort versus luck for advancing in life. Perhaps surprisingly, in the majority of cases we do not find that the East-West divide or the crisis have strong explanatory power, suggesting that opinions about market and democracy may be particularly salient.

At the same time, we find some interesting patterns when we look at attitudes toward competition, preferences for equality, and opinions about whether economic growth is more important than political liberties. In the first column of Table 6, we replicate our baseline results using a variable capturing whether the respondent believes that competition is good and stimulates people to work hard and develop new ideas, as opposed to competition being 
bad and bringing out the worst in people (coded on a 1-10 scale, where 1 is complete support for competition). While the East dummy is not significant, we find that households affected by the crisis in West Ukraine are less likely to favor competition, which is consistent with our earlier findings on preferences for market economy. Interestingly, an opposite pattern emerges in the second column, which shows that crisis-hit Western Ukrainian households are less likely to be in favor of income equality (the dependent variable is again coded on a 1-10 scale, with 1 signifying complete support for equality). Finally, the third column of Table 6 replicates our baseline results using as a dependent variable a dummy for whether the respondent believes that economic growth is more important than political liberties. Eastern Ukrainians are around $36 \%$ more likely to believe that political liberties are more important, though there is some evidence that households affected by the financial crisis are more likely to be in favor of economic growth.

\subsection{Suggestive mechanisms}

\subsubsection{Early transition paths}

Is our dummy for East Ukraine simply a proxy for post-transition economic differences between the two parts of the country? We test this in Table 7, in which we control for the PSU-level decline in economic activity between 1992 and 2006 using light intensity data from the National Oceanic and Atmospheric Administration (NOAA). ${ }^{12}$ Localities which experienced a more adverse transition shock were more likely to favor democracy, perhaps because democratic institutions (such as those in Western Europe) may have been implicitly associated with a stronger safety net. However, respondents in places which experienced a deep and pro-longed economic contraction are no less likely to support the market. While the coefficients on our main variables of interest remain broadly unchanged, we find that the

\footnotetext{
${ }^{12}$ See Henderson et al. (2012) for a discussion of the use of light intensity data as a proxy for economic development.
} 
negative link between the East dummy and preferences for democracy (but not the market) seems to be driven by households in localities in which economic activity decreased more during the transition shock of the early 1990s. ${ }^{13}$

These results support the conjecture that the large attitudinal differences between East and West in terms of democratic support in part reflect deeper cultural differences. Indeed, re-running our baseline specification for support for democracy only (in unreported results) with the 2006 wave of the LiTS (using the East dummy only) produces coefficients on the East dummy which are not statistically different from those obtained using the 2010 data.

\subsubsection{Russian language and media}

Are our results driven simply by the fact that Ukraine's Russian-speaking population is less favorable toward the market and democracy due to ties with Russia? In Table 8, we investigate whether our East dummy is a proxy for language differences between Russianspeaking East Ukraine and West Ukraine. In columns (2) and (4), we control for whether the respondent is a Russian speaker. Our main results (for market economy) remain unchanged, suggesting that mere language differences (and the associated cultural differences for which they proxy) cannot explain our earlier findings. This implies that the cultural cleavages between East and West Ukraine run deeper than simple differences in the dominant language in each region. ${ }^{14}$

However, we also find that Russian speakers and those living in Russian-dominated localities are less likely to be in favor of democratic institutions. In addition, the inclusion of a Russian-speaker dummy weakens the coefficient on the East dummy (for the regressions assessing the drivers of preferences for democracy). This suggests that preferences for democracy (but not the market) in East Ukraine are partially explained by the specific preferences

\footnotetext{
${ }^{13}$ This also holds when we measure the decline in light intensity as a percentage relative to the 1992 level.

${ }^{14}$ We obtain similar results when we use the overall share of Russian speakers in a locality, dummies for a share above $20 \%$ or $50 \%$, or the number of years a particular locality was under Russian jurisdiction or part of the Soviet Union (unreported).
} 
of Russian-speaking households (and households living in Russian-speaking communities).

In Table 9 we study to what extent our results are driven by the prevalence of Russianlanguage media, rather than Russian speaking population. We exploit 2010 TV broadcasting data from the Ukrainian State Statistical Committee (Statistical Bulletin 2010). This allows us to include controls for the share of Russian-language TV broadcasting relative to all regional TV broadcasting. Although the regional Russian-language broadcasting is positively related to the share of Russian speakers in the respective region (correlation coefficient of 0.41), the correlation is not perfect. In fact, some of the oblast with most Russian speakers, such as Donetsk and Luhansk, do not broadcast any regional TV in Russian. ${ }^{15}$ Respondents living in regions with more prevalent Russian-language media are less likely to support democracy, but not any different when it comes to preferences for the market. At the same time, the coefficients on the East dummy, the crisis variable and their interaction, remain unchanged. ${ }^{16}$

\subsubsection{A comparison between Ukraine and Germany}

To what extent are our results for Ukraine applicable to other countries with strong regional divisions? One way to test this is to rerun our regressions using data from East and West Germany, which we do in Table 10 (Germany was included in the 2010 round of the LiTS as a 'comparator' country). Of course, one caveat to interpreting the results is that the historical processes which led to a divided Germany were very different from those in Ukraine. Indeed, Table 10 reveals a very different pattern: East Germans are around $12.5 \%$ less likely to support the market, though this result is borderline significant (columns 1 and 2). ${ }^{17}$ Unlike in Ukraine, democratic preferences do not seem to differ between East and West Germany.

\footnotetext{
${ }^{15}$ These data do not capture viewership of TV channels directly broadcast from Russia.

${ }^{16}$ These results also hold when we measure Russian-language broadcasting as average daily hours of Russian-language TV broadcasting of regional channels.

${ }^{17}$ Splitting the sample into East and West reveals that both East and West Germans who were hit harder by the crisis were equally disappointed with the market.
} 
Moreover, political and economic attitudes in Germany were not affected by the recent financial crisis.

\section{Conclusion}

We exploit the 2010 round of the Life in Transition Survey to show that Eastern Ukrainians are significantly less likely to support a market-based economic system and democratic institutions relative to their Western Ukrainian counterparts. Importantly, these preferences are not immune to external influences. We document that Western households who were hit harder by the Great Recession are much more disenchanted with the market and became more like their Eastern peers in terms of their (lack of) market support. We find a similar, albeit less robust, effect when it comes to democratic preferences.

Our results imply that deep-rooted factors and more short-lived macroeconomic shocks can interact to determine pro-market preferences, and that the effects of financial crises on attitudes may be heterogeneous geographically. As a result, short-term economic volatility caused by financial globalization may quickly undermine public support for market institutions. If persistent, such changing preferences could even lead to reform reversals by driving countries toward less liberal economic systems.

More suggestively, our results can also be viewed through the lens of the literature that studies the emergence of civil conflict and violence. One group of scholars argues that economic grievances (such as those arising from poverty or economic inequality) may be responsible for the emergence of war (Brückner and Ciccone 2010; Collier and Hoeffler 2004).

Others stress that deep-rooted cultural differences are typically at the heart of conflict (Huntington 1993; Montalvo and Reynal-Querol 2005). For the case of Ukraine, both mechanisms may be at work, as social cleavages appear to be driven by deep-rooted factors as well as by transient shocks such as the global financial crisis. 


\section{References}

(???): "Culture and Institutions: Economic Development in the Regions of Europe, author=Tabellini, Guido, journal=Journal of the European Economic Association, volume $=8$, number $=4$, pages $=677-716$, year $=2010$, publisher $=$ Wiley Online Library," .

Ahunov, M., L. Van Hove, And M. Jegers (2013): "Selection and Hidden Bias in Cross-Border Bank Acquisitions: Ukraine's Takeover Wave," EBRD working paper.

Alesina, A. And N. Fuchs-Schündeln (2007): "Good-Bye Lenin (or Not?): The Effect of Communism on People's Preferences," American Economic Review, 97, 1507-1528.

Alesina, A., P. Giuliano, And N. Nunn (2013): "On the Origins of Gender Roles: Women and the Plough," Quarterly Journal of Economics, 128, 469-530.

Algan, Y. And P. Cahuc (2010): "Inherited Trust and Growth," American Economic Review, 5, 2060-2092.

Ananyev, M. And S. Guriev (2013): "Effect of Income on Trust: Evidence from 2009 Crisis in Russia," Working paper.

Becker, S. O., K. Boeckh, C. Hainz, and L. Woessmann (2014): "The Empire Is Dead, Long Live the Empire! Long-Run Persistence of Trust and Corruption in the Bureaucracy," The Economic Journal.

Bisin, A. And T. Verdier (2001): "The Economics of Cultural Transmission and the Dynamics of Preferences," Journal of Economic Theory, 97, 298-319.

BrüCKner, M. And A. Ciccone (2010): "International Commodity Prices, Growth and the Outbreak of Civil War in Sub-Saharan Africa," The Economic Journal, 120, 519-534.

Cameron, A. C., J. B. Gelbach, And D. L. Miller (2008): "Bootstrap-Based Improvements for Inference with Clustered Errors," Review of Economics and Statistics, 90, $414-427$.

Collier, P. And A. Hoeffler (2004): "Greed and Grievance in Civil War," Oxford Economic Papers, 56, 563-595.

Commander, S. J., O. Nikolaychuk, And D. Vikhrov (2013): "Migration from Ukraine: Brawn or Brain? New Survey Evidence," IZA Discussion Paper.

De HaAs, R. And I. VAn Lelyveld (2014): "Multinational Banks and the Global Financial Crisis: Weathering the Perfect Storm?" Journal of Money Credit, and Banking, 46, $333-364$.

Di Tella, R., S. Galiant, and E. Schargrodsky (2007): "The Formation of Beliefs: Evidence from the Allocation of Land Titles to Squatters," Quarterly Journal of Economics, 122, 209-241. 
Dushkevych, N. And V. Zelenyuk (2007): "Ukrainian Banking Sector: Evolution and Current Stage," Ukrainian Observer, 225, 951.

Fisman, R., P. Jakiela, And S. Kariv (2013): "How Did the Great Recession Impact Social Preferences?" Unpublished Manuscript.

Giuliano, P. And A. Spilimbergo (2014): "Growing up in a Recession," Review of Economic Studies, 81, 787-817.

Gorodnichenko, Y. And G. Roland (2011): "Individualism, Innovation, and Long-run Growth," Proceedings of the National Academy of Sciences, 108, 21316-21319.

Grosfeld, I., A. Rodnyansky, And E. Zhuravskaya (2013): "Persistent Anti-Market Culture: a Legacy of the Pale of Settlement after the Holocaust," American Economic Journal: Economic Policy, 5.

Grosjean, P., F. Ricka, and C. Senik (2013): "Learning, Political Attitudes and Crises: Lessons from Transition Countries," Journal of Comparative Economics, 41, 490-505.

Guiso, L., P. Sapienza, And L. Zingales (2006): "Does Culture Affect Economic Outcomes?" Journal of Economic Perspectives, 20, 23-48.

Henderson, J. V., A. Storeygard, And D. N. Weil (2012): "Measuring Economic Growth from Outer Space," The American Economic Review, 102, 994-1028.

Huntington, S. P. (1993): "The Clash of Civilizations?" Foreign Affairs, 22-49.

Kuziemko, I., M. I. Norton, E. Saez, and S. Stantcheva (2013): "How Elastic are Preferences for Redistribution? Evidence from Randomized Survey Experiments," NBER working paper.

Margalit, Y. (2013): "Explaining social policy preferences: Evidence from the Great Recession," American Political Science Review, 107, 80-103.

Mian, A., A. Sufi, And F. Trebbi (2014): "Resolving Debt Overhang: Political Constraints in the Aftermath of Financial Crises," American Economic Journal: Macroeconomics, 6, 1-28.

Montalvo, J. G. and M. Reynal-Querol (2005): "Ethnic Polarization, Potential Conflict, and Civil Wars," American Economic Review, 796-816.

Nikolova, E. And D. Simroth (2015): "Religious Diversity and Entrepreneurship in Transition: Lessons for Policymakers," IZA Journal of European Labor Studies, 4, 1-21.

Nunn, N. And L. Wantchekon (2011): "The Slave Trade and the Origins of Mistrust in Africa," American Economic Review, 101, 3221-3252. 
Pande, R. And C. Udry (2005): "Institutions and Development: A View from Below," in The Proceedings of the 9th World Congress of the Econometric Society. Cambridge University Press.

Popov, A. And G. F. Udell (2012): "Cross-Border Banking, Credit Access, and the Financial Crisis," Journal of International Economics, 87, 147-161.

Putnam, R. D., R. Leonardi, And R. Y. Nanetti (1994): Making Democracy Work: Civic Traditions in Modern Italy, Princeton University Press.

Statistical Bulletin (2010): "Media and Publishing in Ukraine in 2010," State Statistics Committee of Ukraine.

Voigtländer, N. And H.-J. Voth (2012): "Persecution Perpetuated: the Medieval Origins of Anti-Semitic Violence in Nazi Germany," Quarterly Journal of Economics, 127, 1339-1392. 
Figure 1: Preferences for market economy and democracy in east vs. west Ukraine, 2006 and 2010

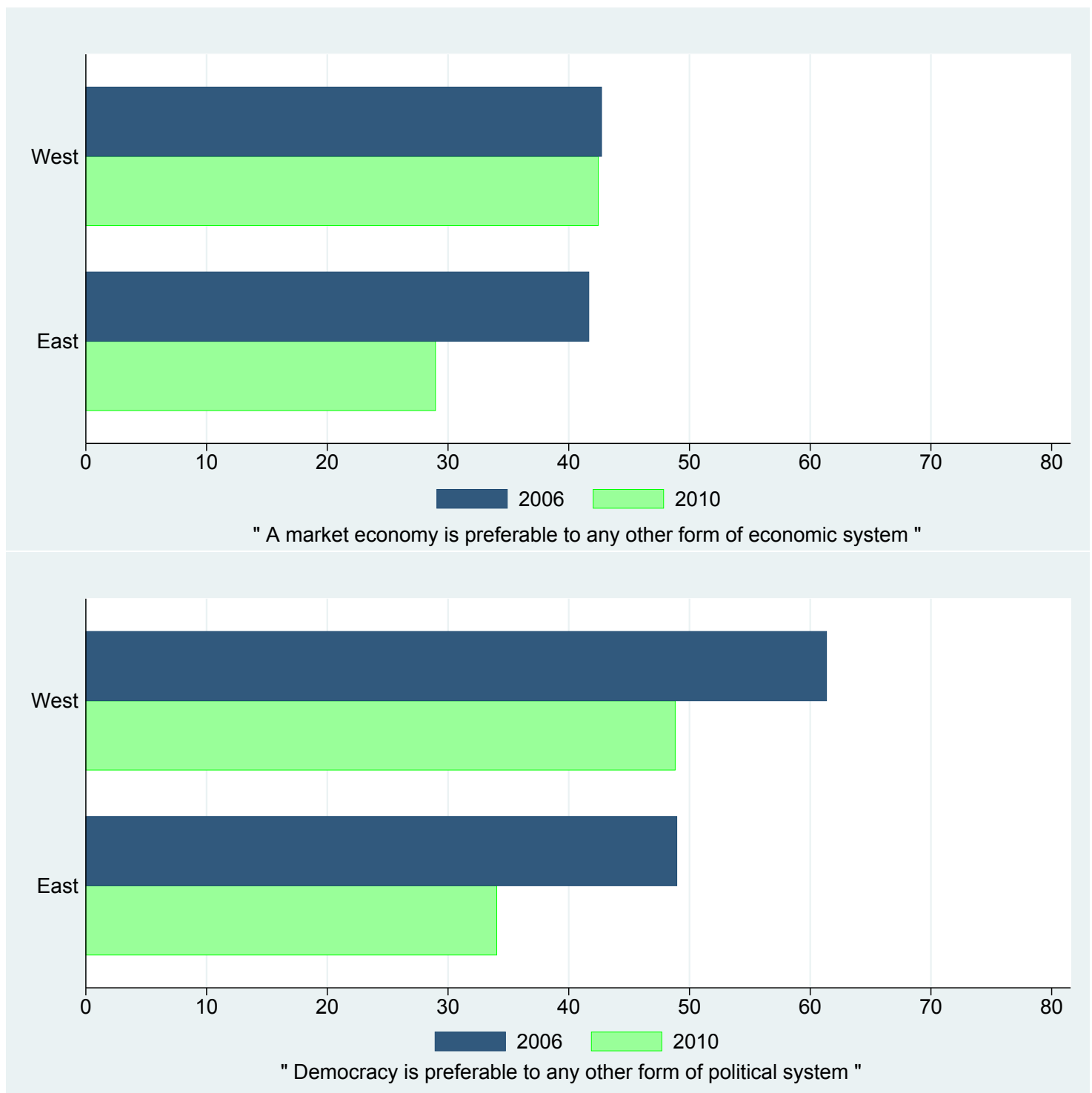

Source: LiTS 2006 and 2010. 
Figure 2: Support for market economy across countries

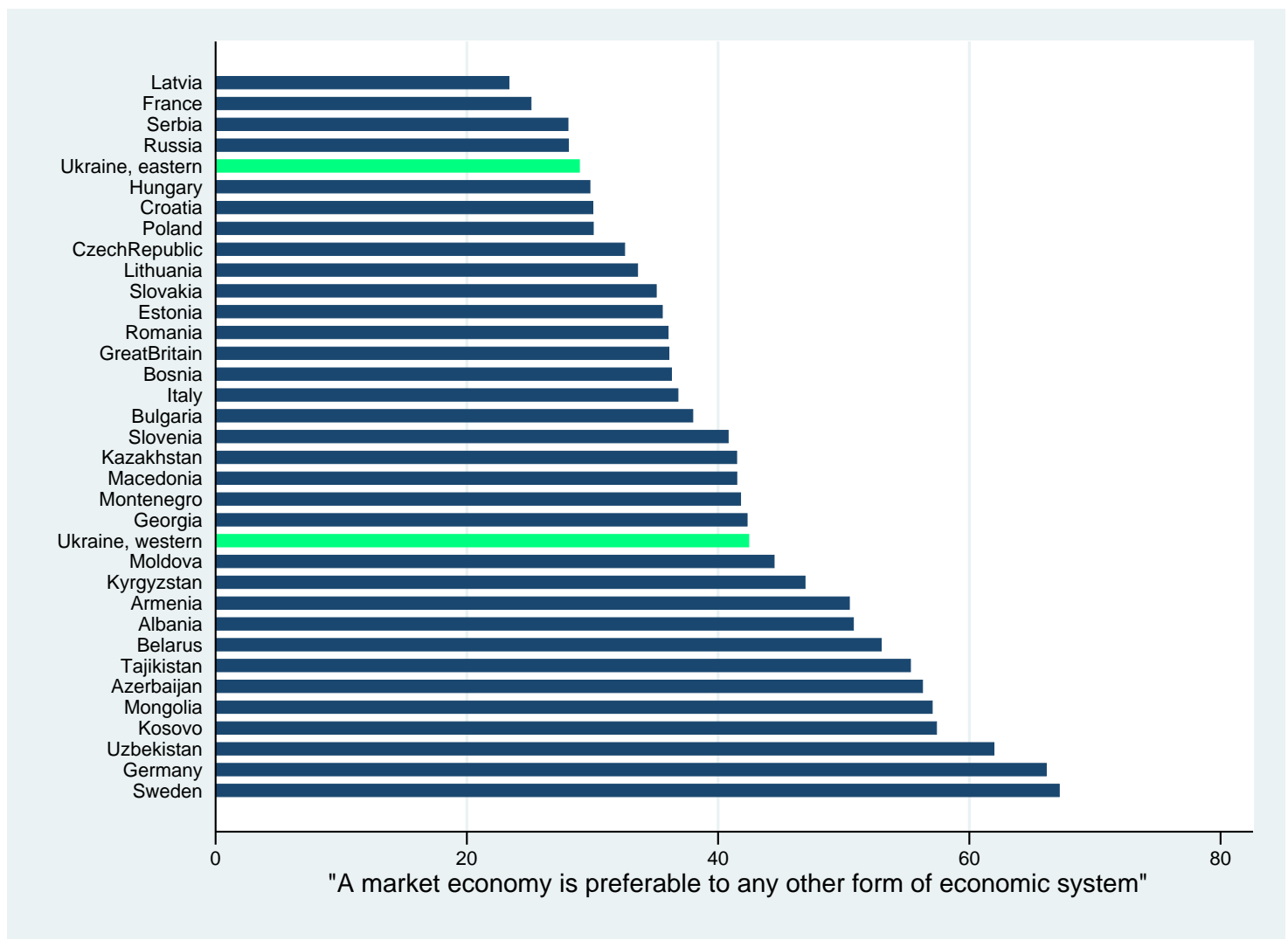

Source: LiTS 2010. Notes: Green bars: east and west Ukraine. 
Figure 3: Support for democracy across countries

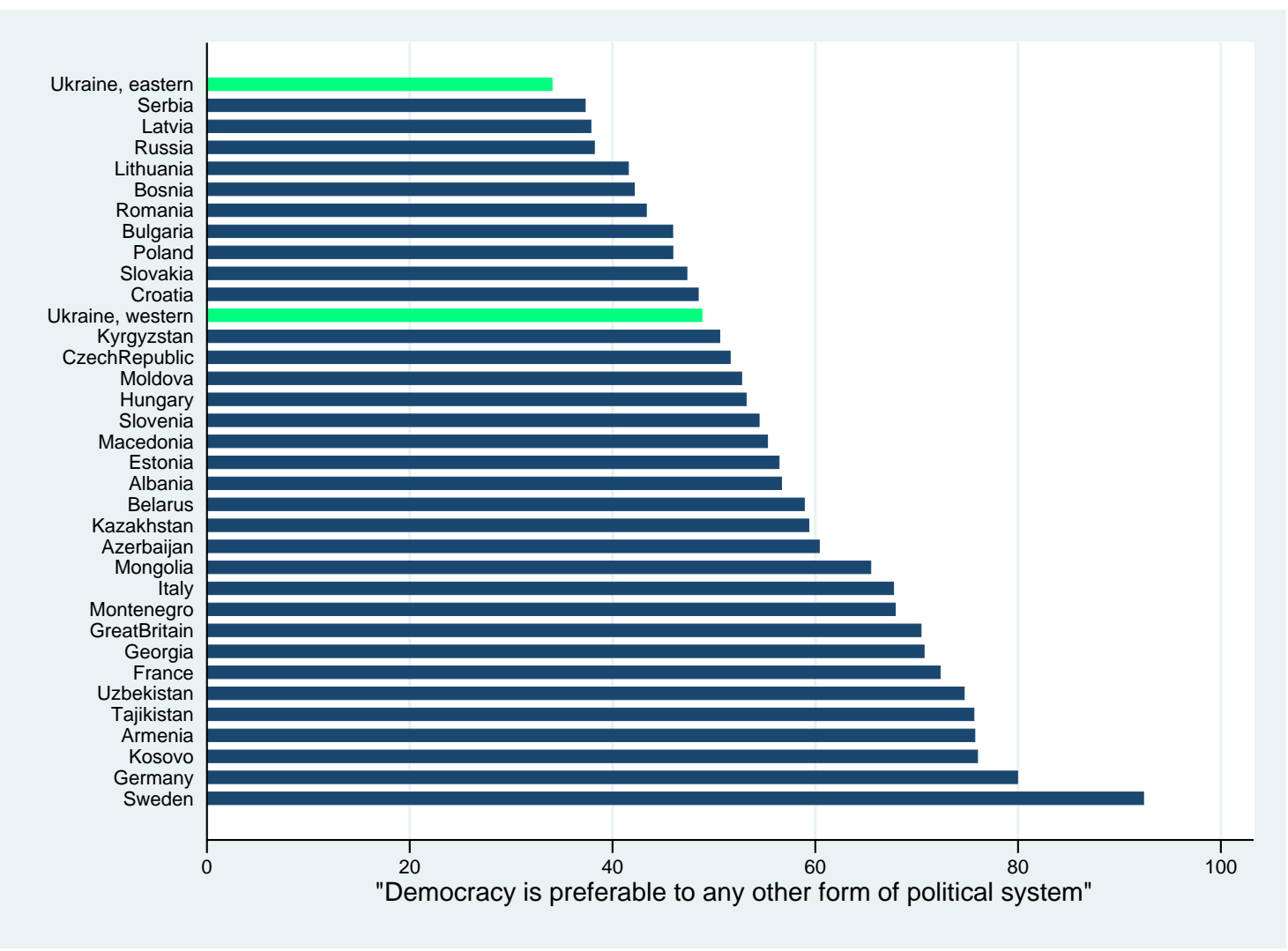

Source: LiTS 2010. Notes: Green bars: east and west Ukraine. 
Figure 4: Effect of the financial crisis on market preferences in east vs. west Ukraine

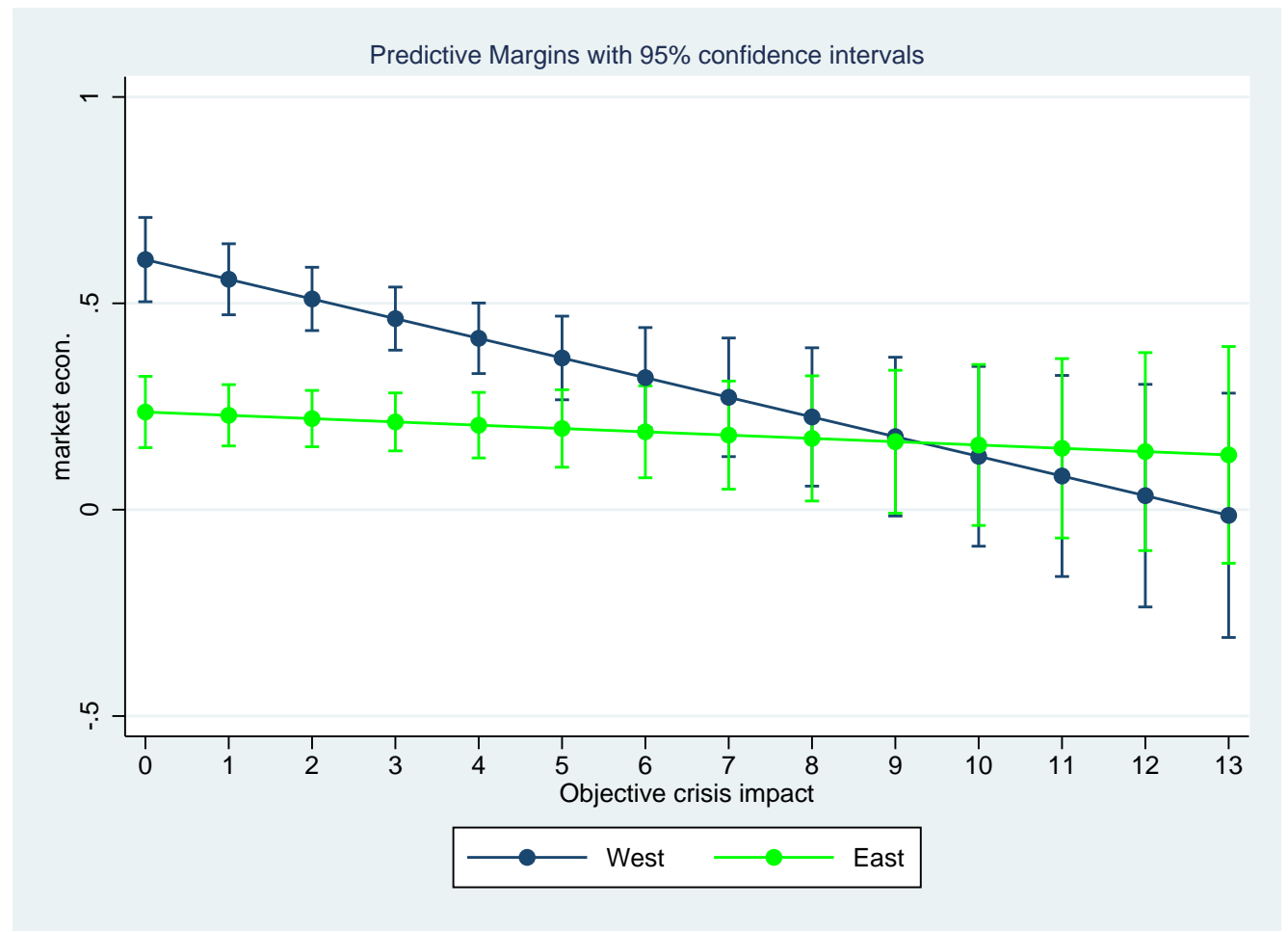

Source: LiTS 2010. Notes: This chart plots coefficient estimates from column (1), Table 1. 
Table 1: Preferences for a market economy in east and west Ukraine

\begin{tabular}{|c|c|c|c|c|}
\hline & & & West & East \\
\hline & (1) & $(2)$ & (3) & $(4)$ \\
\hline & \multicolumn{4}{|c|}{ Market economy preferable } \\
\hline East & $\begin{array}{c}-0.369^{* * *} \\
(0.079)\end{array}$ & $\begin{array}{c}-0.338^{* * *} \\
(0.081)\end{array}$ & & \\
\hline Objective crisis impact & $\begin{array}{c}-0.048^{* * *} \\
(0.014)\end{array}$ & & $\begin{array}{c}-0.059^{* * *} \\
(0.015)\end{array}$ & $\begin{array}{c}0.004 \\
(0.012)\end{array}$ \\
\hline East $*$ Objective crisis impact & $\begin{array}{c}0.040^{* *} \\
(0.018)\end{array}$ & & & \\
\hline Subjective crisis impact & & $\begin{array}{c}-0.056^{* *} \\
(0.023)\end{array}$ & & \\
\hline East $*$ Subjective crisis impact & & $\begin{array}{l}0.078^{* * *} \\
(0.030)\end{array}$ & & \\
\hline Age & $\begin{array}{c}0.001 \\
(0.005)\end{array}$ & $\begin{array}{c}0.003 \\
(0.006)\end{array}$ & $\begin{array}{c}0.005 \\
(0.008)\end{array}$ & $\begin{array}{r}-0.008 \\
(0.008)\end{array}$ \\
\hline $\mathrm{Age}^{2}$ & $\begin{array}{c}-0.000 \\
(0.000)\end{array}$ & $\begin{array}{c}-0.000 \\
(0.000)\end{array}$ & $\begin{array}{c}-0.000 \\
(0.000)\end{array}$ & $\begin{array}{c}0.000 \\
(0.000)\end{array}$ \\
\hline Unemployed excl. start-up & $\begin{array}{c}-0.132^{* * *} \\
(0.040)\end{array}$ & $\begin{array}{c}-0.107^{* * *} \\
(0.041)\end{array}$ & $\begin{array}{c}-0.121^{* *} \\
(0.060)\end{array}$ & $\begin{array}{c}-0.124^{* *} \\
(0.053)\end{array}$ \\
\hline Start-up & $\begin{array}{c}0.104 \\
(0.070)\end{array}$ & $\begin{array}{c}0.120 \\
(0.076)\end{array}$ & $\begin{array}{c}0.138 \\
(0.109)\end{array}$ & $\begin{array}{c}0.063 \\
(0.092)\end{array}$ \\
\hline Income & $\begin{array}{c}0.022^{*} \\
(0.012)\end{array}$ & $\begin{array}{l}0.030^{* *} \\
(0.012)\end{array}$ & $\begin{array}{c}0.016 \\
(0.018)\end{array}$ & $\begin{array}{c}0.027^{*} \\
(0.016)\end{array}$ \\
\hline Secondary education & $\begin{array}{c}0.144 \\
(0.090)\end{array}$ & $\begin{array}{c}0.150 \\
(0.096)\end{array}$ & $\begin{array}{c}0.184^{*} \\
(0.106)\end{array}$ & $\begin{array}{c}0.068 \\
(0.145)\end{array}$ \\
\hline Post-secondary / university degree & $\begin{array}{l}0.181^{* *} \\
(0.091)\end{array}$ & $\begin{array}{c}0.200^{* *} \\
(0.095)\end{array}$ & $\begin{array}{c}0.199^{*} \\
(0.109)\end{array}$ & $\begin{array}{c}0.137 \\
(0.142)\end{array}$ \\
\hline Male & $\begin{array}{c}-0.077^{* *} \\
(0.034)\end{array}$ & $\begin{array}{c}-0.081^{* *} \\
(0.036)\end{array}$ & $\begin{array}{c}-0.152^{* * *} \\
(0.047)\end{array}$ & $\begin{array}{c}0.008 \\
(0.050)\end{array}$ \\
\hline Health & $\begin{array}{l}0.058^{* * *} \\
(0.022)\end{array}$ & $\begin{array}{c}0.060^{* *} \\
(0.024)\end{array}$ & $\begin{array}{c}0.034 \\
(0.032)\end{array}$ & $\begin{array}{l}0.088^{* * *} \\
(0.030)\end{array}$ \\
\hline Communist & $\begin{array}{r}-0.056^{*} \\
(0.034)\end{array}$ & $\begin{array}{r}-0.070^{*} \\
(0.036)\end{array}$ & $\begin{array}{c}0.009 \\
(0.057)\end{array}$ & $\begin{array}{c}-0.093^{* *} \\
(0.043)\end{array}$ \\
\hline Ever moved & $\begin{array}{r}-0.016 \\
(0.032)\end{array}$ & $\begin{array}{r}-0.022 \\
(0.034)\end{array}$ & $\begin{array}{r}-0.020 \\
(0.049)\end{array}$ & $\begin{array}{c}0.003 \\
(0.044)\end{array}$ \\
\hline Urban & $\begin{array}{c}0.019 \\
(0.035)\end{array}$ & $\begin{array}{c}0.017 \\
(0.035)\end{array}$ & $\begin{array}{c}0.116^{* *} \\
(0.048)\end{array}$ & $\begin{array}{r}-0.077 \\
(0.050)\end{array}$ \\
\hline Longitude & $\begin{array}{c}0.004 \\
(0.006)\end{array}$ & $\begin{array}{c}0.000 \\
(0.006)\end{array}$ & $\begin{array}{c}0.006 \\
(0.008)\end{array}$ & $\begin{array}{c}0.004 \\
(0.010)\end{array}$ \\
\hline Latitude & $\begin{array}{c}-0.049^{* * *} \\
(0.014)\end{array}$ & $\begin{array}{c}-0.048^{* * *} \\
(0.015)\end{array}$ & $\begin{array}{c}-0.114^{* * *} \\
(0.032)\end{array}$ & $\begin{array}{r}-0.028 \\
(0.017)\end{array}$ \\
\hline Observations & 987 & 900 & 480 & 507 \\
\hline
\end{tabular}

Source: LiTS 2010. Notes: This table explores the drivers of preferences for a market economy in eastern and west Ukraine. See the text for more information on the socio-economic and PSU controls included in the regressions. Robust standard errors are in parentheses. Significance levels: ${ }^{*} p<0.1,{ }^{* *} p<0.05,{ }^{* * *}$ $p<0.01$. 
Table 2: Preferences for a market economy in east and west Ukraine: disaggregated crisis impact

\begin{tabular}{|c|c|c|c|c|c|}
\hline & $(1)$ & $(2)$ & $(3)$ & $(4)$ & $(5)$ \\
\hline & \multicolumn{5}{|c|}{ Market economy preferable } \\
\hline East & $\begin{array}{c}-0.326^{* * *} \\
(0.074)\end{array}$ & $\begin{array}{c}-0.284^{* * *} \\
(0.077)\end{array}$ & $\begin{array}{c}-0.266^{* * *} \\
(0.067)\end{array}$ & $\begin{array}{c}-0.268^{* * *} \\
(0.070)\end{array}$ & $\begin{array}{c}-0.268^{* * *} \\
(0.067)\end{array}$ \\
\hline Reduction in foods & $\begin{array}{c}-0.129^{* * *} \\
(0.048)\end{array}$ & & & & \\
\hline East $*$ Reduction in foods & $\begin{array}{c}0.152^{* *} \\
(0.063)\end{array}$ & & & & \\
\hline Reduction in luxury or leisure & & $\begin{array}{c}-0.070 \\
(0.049)\end{array}$ & & & \\
\hline East $*$ Reduction in luxury or leisure & & $\begin{array}{c}0.035 \\
(0.063)\end{array}$ & & & \\
\hline Reduction in educ. & & & $\begin{array}{c}-0.420^{* * *} \\
(0.132)\end{array}$ & & \\
\hline East $*$ Reduction in educ. & & & $\begin{array}{l}0.590^{* * *} \\
(0.171)\end{array}$ & & \\
\hline Reduction in health services & & & & $\begin{array}{r}-0.106^{*} \\
(0.055)\end{array}$ & \\
\hline East $*$ Reduction in health services & & & & $\begin{array}{c}0.020 \\
(0.069)\end{array}$ & \\
\hline Delay in payments on utilities or loans & & & & & $\begin{array}{c}-0.213^{* *} \\
(0.106)\end{array}$ \\
\hline East $*$ Delay in payments on utilities or loans & & & & & $\begin{array}{c}0.245^{*} \\
(0.137)\end{array}$ \\
\hline Individual controls & $\checkmark$ & $\checkmark$ & $\checkmark$ & $\checkmark$ & $\checkmark$ \\
\hline PSU controls & $\checkmark$ & $\checkmark$ & $\checkmark$ & $\checkmark$ & $\checkmark$ \\
\hline Observations & 987 & 987 & 987 & 987 & 987 \\
\hline
\end{tabular}

Source: LiTS 2010. Notes: This table explores the drivers of preferences for a market economy in east and west Ukraine using disaggregated objective crisis-impact indices. See the text for more information on the individual and PSU controls included in the regressions. Robust standard errors are in parentheses. Significance levels: ${ }^{*} p<0.1,{ }^{* *} p<0.05,{ }^{* * *} p<0.01$. 
Table 3: Preferences for democracy in east and west Ukraine

\begin{tabular}{|c|c|c|c|c|}
\hline & & & West & East \\
\hline & (1) & $(2)$ & (3) & (4) \\
\hline & \multicolumn{4}{|c|}{ Democracy preferable } \\
\hline East & $\begin{array}{c}-0.425^{* * *} \\
(0.076)\end{array}$ & $\begin{array}{c}-0.349^{* * *} \\
(0.079)\end{array}$ & & \\
\hline Objective crisis impact & $\begin{array}{r}-0.020 \\
(0.012)\end{array}$ & & $\begin{array}{c}-0.027^{* *} \\
(0.013)\end{array}$ & $\begin{array}{c}0.016 \\
(0.012)\end{array}$ \\
\hline East $*$ Objective crisis impact & $\begin{array}{c}0.032^{*} \\
(0.016)\end{array}$ & & & \\
\hline Subjective crisis impact & & $\begin{array}{c}-0.019 \\
(0.023)\end{array}$ & & \\
\hline East $*$ Subjective crisis impact & & $\begin{array}{c}0.008 \\
(0.030)\end{array}$ & & \\
\hline Age & $\begin{array}{c}0.011^{* *} \\
(0.006)\end{array}$ & $\begin{array}{l}0.013^{* *} \\
(0.006)\end{array}$ & $\begin{array}{c}0.008 \\
(0.008)\end{array}$ & $\begin{array}{c}0.008 \\
(0.008)\end{array}$ \\
\hline $\mathrm{Age}^{2}$ & $\begin{array}{r}-0.000^{*} \\
(0.000)\end{array}$ & $\begin{array}{c}-0.000^{*} \\
(0.000)\end{array}$ & $\begin{array}{c}-0.000 \\
(0.000)\end{array}$ & $\begin{array}{c}-0.000 \\
(0.000)\end{array}$ \\
\hline Unemployed excl. start-up & $\begin{array}{r}-0.030 \\
(0.040)\end{array}$ & $\begin{array}{r}-0.026 \\
(0.041)\end{array}$ & $\begin{array}{c}0.013 \\
(0.062)\end{array}$ & $\begin{array}{r}-0.074 \\
(0.054)\end{array}$ \\
\hline Start-up & $\begin{array}{c}0.162^{* *} \\
(0.076)\end{array}$ & $\begin{array}{c}0.177^{* *} \\
(0.078)\end{array}$ & $\begin{array}{c}0.167 \\
(0.113)\end{array}$ & $\begin{array}{c}0.123 \\
(0.106)\end{array}$ \\
\hline Income & $\begin{array}{c}0.018 \\
(0.012)\end{array}$ & $\begin{array}{c}0.019 \\
(0.013)\end{array}$ & $\begin{array}{c}0.010 \\
(0.018)\end{array}$ & $\begin{array}{c}0.027^{*} \\
(0.016)\end{array}$ \\
\hline Secondary education & $\begin{array}{c}0.119 \\
(0.091)\end{array}$ & $\begin{array}{l}0.198^{* *} \\
(0.097)\end{array}$ & $\begin{array}{c}0.258^{* *} \\
(0.110)\end{array}$ & $\begin{array}{r}-0.058 \\
(0.161)\end{array}$ \\
\hline Post-secondary / university degree & $\begin{array}{c}0.163^{*} \\
(0.092)\end{array}$ & $\begin{array}{c}0.238^{* *} \\
(0.096)\end{array}$ & $\begin{array}{c}0.251^{* *} \\
(0.116)\end{array}$ & $\begin{array}{c}0.041 \\
(0.158)\end{array}$ \\
\hline Male & $\begin{array}{r}-0.054 \\
(0.034)\end{array}$ & $\begin{array}{c}-0.060^{*} \\
(0.035)\end{array}$ & $\begin{array}{c}-0.086^{*} \\
(0.048)\end{array}$ & $\begin{array}{c}0.001 \\
(0.048)\end{array}$ \\
\hline Health & $\begin{array}{c}0.039 \\
(0.024)\end{array}$ & $\begin{array}{c}0.044^{*} \\
(0.025)\end{array}$ & $\begin{array}{c}0.036 \\
(0.034)\end{array}$ & $\begin{array}{c}0.051 \\
(0.032)\end{array}$ \\
\hline Communist & $\begin{array}{c}-0.023 \\
(0.035)\end{array}$ & $\begin{array}{c}-0.015 \\
(0.037)\end{array}$ & $\begin{array}{r}-0.017 \\
(0.055)\end{array}$ & $\begin{array}{c}0.008 \\
(0.045)\end{array}$ \\
\hline Ever moved & $\begin{array}{r}-0.013 \\
(0.033)\end{array}$ & $\begin{array}{r}-0.008 \\
(0.035)\end{array}$ & $\begin{array}{r}-0.007 \\
(0.050)\end{array}$ & $\begin{array}{c}0.008 \\
(0.046)\end{array}$ \\
\hline Urban & $\begin{array}{c}0.044 \\
(0.035)\end{array}$ & $\begin{array}{c}0.059 \\
(0.036)\end{array}$ & $\begin{array}{c}0.053 \\
(0.050)\end{array}$ & $\begin{array}{c}0.050 \\
(0.047)\end{array}$ \\
\hline Longitude & $\begin{array}{c}0.005 \\
(0.006)\end{array}$ & $\begin{array}{c}0.005 \\
(0.007)\end{array}$ & $\begin{array}{c}0.004 \\
(0.008)\end{array}$ & $\begin{array}{c}0.015 \\
(0.010)\end{array}$ \\
\hline Latitude & $\begin{array}{c}-0.075^{* * *} \\
(0.014)\end{array}$ & $\begin{array}{c}-0.078^{* * *} \\
(0.015)\end{array}$ & $\begin{array}{c}-0.181^{* * *} \\
(0.032)\end{array}$ & $\begin{array}{c}-0.055^{* * *} \\
(0.017)\end{array}$ \\
\hline Observations & 1016 & 924 & 490 & 526 \\
\hline
\end{tabular}

Source: LiTS 2010. Notes: This table explores the drivers of preferences for democracy in east and west Ukraine. See the text for more information on the individual and PSU controls included in the regressions. Robust standard errors are in parentheses. Significance levels: ${ }^{*} p<0.1,{ }^{* *} p<0.05,{ }^{* * *} p<0.01$. 
Table 4: Preferences for a market economy in east and west Ukraine: IV specifications

\begin{tabular}{|c|c|c|c|c|c|c|}
\hline & \multicolumn{3}{|c|}{ West } & \multicolumn{3}{|c|}{ East } \\
\hline & $(1)$ & $(2)$ & $(3)$ & $(4)$ & $(5)$ & $(6)$ \\
\hline & OLS & IV & IV & OLS & IV & IV \\
\hline & \multicolumn{6}{|c|}{ Market economy preferable } \\
\hline Objective crisis impact & $\begin{array}{c}-0.052^{* * *} \\
(0.016)\end{array}$ & $\begin{array}{c}-0.205^{* *} \\
(0.083)\end{array}$ & $\begin{array}{l}-0.172^{* * *} \\
(0.057)\end{array}$ & $\begin{array}{r}-0.005 \\
(0.014)\end{array}$ & $\begin{array}{r}-0.157 \\
(0.101)\end{array}$ & $\begin{array}{c}-0.040 \\
(0.046)\end{array}$ \\
\hline Socio-economic controls & $\checkmark$ & $\checkmark$ & $\checkmark$ & $\checkmark$ & $\checkmark$ & $\checkmark$ \\
\hline PSU controls & $\checkmark$ & $\checkmark$ & $\checkmark$ & $\checkmark$ & $\checkmark$ & $\checkmark$ \\
\hline $\begin{array}{l}\text { F-stat. } \\
\text { Wholesale funding }\end{array}$ & & $\begin{array}{l}15.69 \\
0.011^{* * *} \\
(0.003)\end{array}$ & 29.94 & & $\begin{array}{l}11.38 \\
0.012^{* * *} \\
(0.004)\end{array}$ & 20.30 \\
\hline Wholesale funding, excluding new branches & & & $\begin{array}{l}0.010^{* * *} \\
(0.002)\end{array}$ & & & $\begin{array}{l}0.016^{* * *} \\
(0.004)\end{array}$ \\
\hline Observations & 366 & 366 & 333 & 331 & 331 & 299 \\
\hline
\end{tabular}

Source: LiTS 2010. Notes: This table explores the drivers of preferences for a market economy in east and west Ukraine using IV estimations. See the text for more information on the individual and PSU controls included in the regressions. Robust standard errors are in parentheses. Significance levels: ${ }^{*} p<0.1,{ }^{* *} p<0.05,{ }^{* * *} p<0.01$. 
Table 5: Preferences for market economy in east and west Ukraine: robustness

\begin{tabular}{|c|c|c|c|c|}
\hline & $(1)$ & $(2)$ & (3) & $(4)$ \\
\hline & \multicolumn{3}{|c|}{ Market economy preferable } & Favour private ownership \\
\hline East & $\begin{array}{c}-0.355^{* * *} \\
(0.080)\end{array}$ & $\begin{array}{c}-0.324^{* * *} \\
(0.083)\end{array}$ & $\begin{array}{c}-0.374^{* * *} \\
(0.080)\end{array}$ & $\begin{array}{c}-2.385^{* * *} \\
(0.425)\end{array}$ \\
\hline Objective crisis impact & $\begin{array}{c}-0.047^{* * *} \\
(0.014)\end{array}$ & $\begin{array}{c}-0.046^{* * *} \\
(0.014)\end{array}$ & $\begin{array}{c}-0.050^{* * *} \\
(0.014)\end{array}$ & $\begin{array}{c}-0.199^{* * *} \\
(0.065)\end{array}$ \\
\hline East $*$ Objective crisis impact & $\begin{array}{l}0.039^{* *} \\
(0.018)\end{array}$ & $\begin{array}{c}0.036^{* *} \\
(0.018)\end{array}$ & $\begin{array}{c}0.042^{* *} \\
(0.018)\end{array}$ & $\begin{array}{c}0.236^{* *} \\
(0.097)\end{array}$ \\
\hline Emigration rate & $\begin{array}{r}-0.002 \\
(0.002)\end{array}$ & $\begin{array}{r}-0.001 \\
(0.002)\end{array}$ & & \\
\hline Share of emigrants to Russia & & $\begin{array}{c}0.002 \\
(0.003)\end{array}$ & & \\
\hline Share of emigrants to EU27 & & $\begin{array}{c}0.003 \\
(0.003)\end{array}$ & & \\
\hline Share of emigrants to ROW & & $\begin{array}{c}0.000 \\
(0.003)\end{array}$ & & \\
\hline Asset count & & & $\begin{array}{c}0.021^{*} \\
(0.012)\end{array}$ & \\
\hline Socio-economic controls & $\checkmark$ & $\checkmark$ & $\checkmark$ & $\checkmark$ \\
\hline PSU controls & $\checkmark$ & $\checkmark$ & $\checkmark$ & $\checkmark$ \\
\hline Observations & 987 & 987 & 987 & 1114 \\
\hline
\end{tabular}

Source: LiTS 2010. Notes: This table explores the drivers of preferences for market economy in east and west Ukraine. See the text for more information on the individual and PSU controls included in the regressions. ROW stands for "rest of the world". Robust standard errors are in parentheses. Significance levels: * $p<0.1$ ** $p<0.05, * * * p<0.01$. 
Table 6: Opinions about competition, equality and the importance of economic growth versus political liberties in east vs. west Ukraine

\begin{tabular}{lcccc}
\hline & $(1)$ & $(2)$ & & $(3)$ \\
& Favor competition & Favor inc. equality & Prefer economic growth over political liberties \\
\cline { 2 - 2 } East & -0.295 & & $-0.863^{*}$ & $-0.360^{* * *}$ \\
& $(0.353)$ & & $(0.443)$ & $(0.061)$ \\
Objective crisis impact & $-0.109^{* *}$ & $-0.124^{*}$ & -0.010 \\
& $(0.054)$ & & $(0.064)$ & $(0.010)$ \\
East * Objective crisis impact & 0.111 & & $0.187^{* *}$ & $0.029^{* *}$ \\
Individual controls & $(0.076)$ & & $(0.095)$ & $(0.014)$ \\
PSU controls & $\checkmark$ & $\checkmark$ & $\checkmark$ \\
\hline Observations & $\checkmark$ & $\checkmark$ & $\checkmark$ \\
\hline
\end{tabular}

Source: LiTS 2010. See the text for more information on the individual and PSU controls included in the regressions. Robust standard errors are in parentheses. Significance levels: ${ }^{*} p<0.1,{ }^{* *} p<0.05,{ }^{* * *} p<0.01$. 
Table 7: Suggestive mechanisms: difference in transition paths and preferences for markets and democracy in east vs. west Ukraine

\begin{tabular}{|c|c|c|c|c|}
\hline & (1) & $(2)$ & $(3)$ & $(4)$ \\
\hline & \multicolumn{2}{|c|}{ Market economy preferable } & \multicolumn{2}{|c|}{ Democracy preferable } \\
\hline East & $\begin{array}{c}-0.369^{* * *} \\
(0.079)\end{array}$ & $\begin{array}{c}-0.344^{* * *} \\
(0.081)\end{array}$ & $\begin{array}{c}-0.425^{* * *} \\
(0.076)\end{array}$ & $\begin{array}{c}-0.378^{* * *} \\
(0.076)\end{array}$ \\
\hline Objective crisis impact & $\begin{array}{c}-0.048^{* * *} \\
(0.014)\end{array}$ & $\begin{array}{c}-0.048^{* * *} \\
(0.014)\end{array}$ & $\begin{array}{c}-0.020 \\
(0.012)\end{array}$ & $\begin{array}{c}-0.021^{*} \\
(0.012)\end{array}$ \\
\hline East $*$ Objective crisis impact & $\begin{array}{l}0.040^{* *} \\
(0.018)\end{array}$ & $\begin{array}{l}0.039^{* *} \\
(0.018)\end{array}$ & $\begin{array}{c}0.032^{*} \\
(0.016)\end{array}$ & $\begin{array}{c}0.030^{*} \\
(0.016)\end{array}$ \\
\hline Decline in light intensity & & $\begin{array}{c}0.009^{*} \\
(0.005)\end{array}$ & & $\begin{array}{l}0.017^{* * *} \\
(0.004)\end{array}$ \\
\hline Individual controls & $\checkmark$ & $\checkmark$ & $\checkmark$ & $\checkmark$ \\
\hline PSU controls & $\checkmark$ & $\checkmark$ & $\checkmark$ & $\checkmark$ \\
\hline Observations & 987 & 987 & 1016 & 1016 \\
\hline
\end{tabular}

Source: LiTS 2010. See the text for more information on the individual and PSU controls included in the regressions. Robust standard errors are in parentheses. Significance levels: ${ }^{*} p<0.1,{ }^{* *} p<0.05$, $* * * p<0.01$. 
Table 8: Suggestive mechanisms: language differences and preferences for markets and democracy in east vs. west Ukraine

\begin{tabular}{|c|c|c|c|c|}
\hline \multirow[b]{3}{*}{ East } & (1) & $(2)$ & $(3)$ & $(4)$ \\
\hline & \multicolumn{2}{|c|}{ Market economy preferable } & \multicolumn{2}{|c|}{ Democracy preferable } \\
\hline & $\begin{array}{c}-0.369^{* * *} \\
(0.079)\end{array}$ & $\begin{array}{c}-0.366^{* * *} \\
(0.080)\end{array}$ & $\begin{array}{c}-0.425^{* * *} \\
(0.076)\end{array}$ & $\begin{array}{c}-0.404^{* * *} \\
(0.076)\end{array}$ \\
\hline Objective crisis impact & $\begin{array}{c}-0.048^{* * *} \\
(0.014)\end{array}$ & $\begin{array}{c}-0.048^{* * *} \\
(0.014)\end{array}$ & $\begin{array}{c}-0.020 \\
(0.012)\end{array}$ & $\begin{array}{c}-0.021^{*} \\
(0.012)\end{array}$ \\
\hline East $*$ Objective crisis impact & $\begin{array}{c}0.040^{* *} \\
(0.018)\end{array}$ & $\begin{array}{l}0.040^{* *} \\
(0.018)\end{array}$ & $\begin{array}{c}0.032^{*} \\
(0.016)\end{array}$ & $\begin{array}{c}0.031^{*} \\
(0.017)\end{array}$ \\
\hline Russian speaker & & $\begin{array}{c}-0.012 \\
(0.039)\end{array}$ & & $\begin{array}{c}-0.078^{* *} \\
(0.039)\end{array}$ \\
\hline Individual controls & $\checkmark$ & $\checkmark$ & $\checkmark$ & $\checkmark$ \\
\hline PSU controls & $\checkmark$ & $\checkmark$ & $\checkmark$ & $\checkmark$ \\
\hline Observations & 987 & 987 & 1016 & 1016 \\
\hline
\end{tabular}

Source: LiTS 2010. See the text for more information on the individual and PSU controls included in the regressions. Robust standard errors are in parentheses. Significance levels: ${ }^{*} p<0.1,{ }^{* *} p<0.05$, *** $p<0.01$. 
Table 9: Suggestive mechanisms: Russian language media and preferences for markets and democracy in east vs. west Ukraine

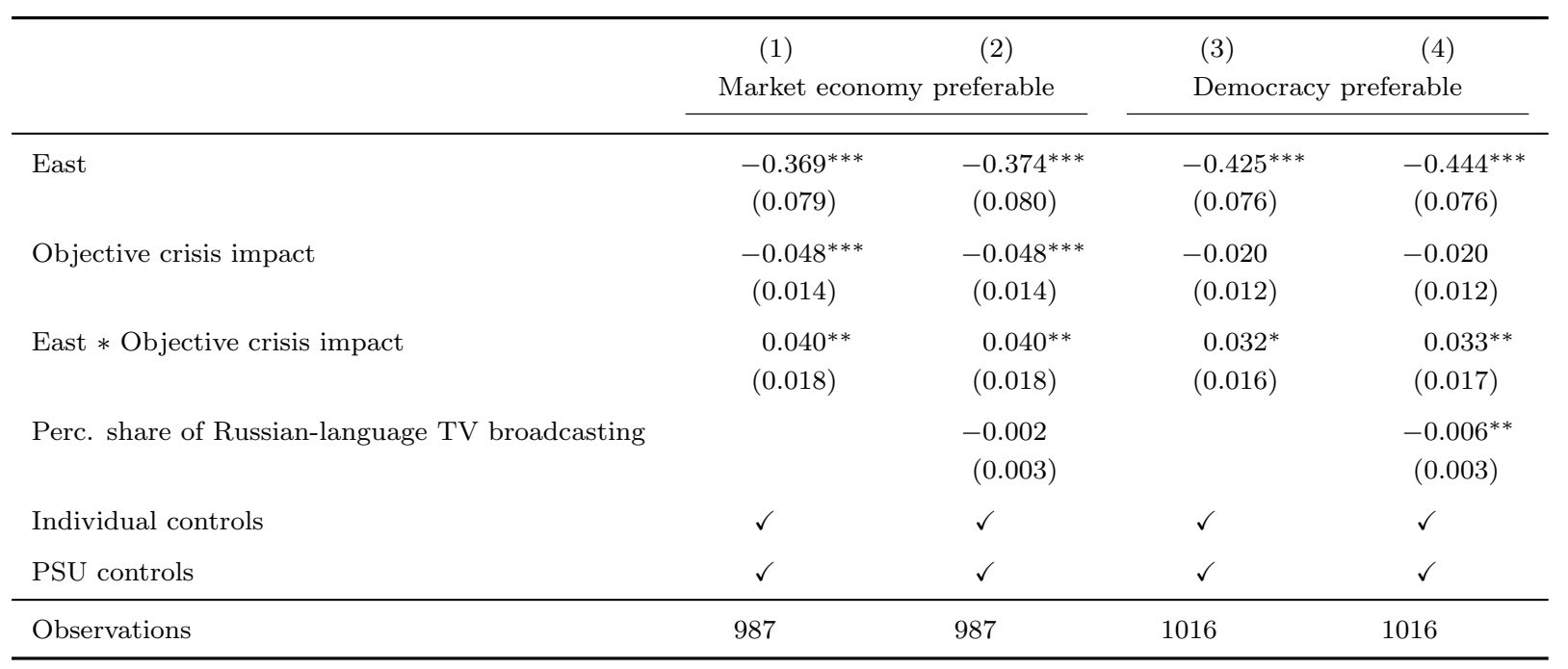

Source: LiTS 2010. See the text for more information on the individual and PSU controls included in the regressions. Robust standard errors are in parentheses. Significance levels: ${ }^{*} p<0.1,{ }^{* *} p<0.05,{ }^{* * *} p<0.01$. 
Table 10: Preferences for markets and democracy in former East and West Germany

\begin{tabular}{|c|c|c|c|c|}
\hline & \multicolumn{2}{|c|}{ Market economy preferable } & \multicolumn{2}{|c|}{ Democracy preferable } \\
\hline & $(1)$ & $(2)$ & (3) & $(4)$ \\
\hline East & $\begin{array}{r}-0.125^{*} \\
(0.064)\end{array}$ & $\begin{array}{r}-0.126^{*} \\
(0.064)\end{array}$ & $\begin{array}{c}-0.043 \\
(0.057)\end{array}$ & $\begin{array}{c}0.004 \\
(0.058)\end{array}$ \\
\hline Objective crisis impact & $\begin{array}{r}-0.017 \\
(0.012)\end{array}$ & & $\begin{array}{c}0.001 \\
(0.010)\end{array}$ & \\
\hline East $*$ Objective crisis impact & $\begin{array}{c}-0.036 \\
(0.022)\end{array}$ & & $\begin{array}{c}0.005 \\
(0.023)\end{array}$ & \\
\hline Subjective crisis impact & & $\begin{array}{c}-0.022 \\
(0.021)\end{array}$ & & $\begin{array}{r}-0.033^{*} \\
(0.019)\end{array}$ \\
\hline East $*$ Subjective crisis impact & & $\begin{array}{r}-0.081^{*} \\
(0.045)\end{array}$ & & $\begin{array}{r}-0.046 \\
(0.045)\end{array}$ \\
\hline Individual controls & $\checkmark$ & $\checkmark$ & $\checkmark$ & $\checkmark$ \\
\hline PSU controls & $\checkmark$ & $\checkmark$ & $\checkmark$ & $\checkmark$ \\
\hline Observations & 979 & 955 & 998 & 974 \\
\hline
\end{tabular}

Source: LiTS 2010. Notes: This table explores the drivers of preferences for market economy and democracy in former East and West Germany. See the text for more information on the individual and PSU controls included in the regressions. Robust standard errors are in parentheses. Significance levels: ${ }^{*} p<0.1{ }^{* *} p<0.05$, ${ }^{* * *}$ $p<0.01$. 